\title{
NEŽYMIAI SUTRIKUSIO INTELEKTO MOKINIAI \\ GEOGRAFIJOS PAMOKOSE: EDUKACINIAI YPATUMAI
}

\author{
Regina Subotkevičienè \\ Lietuvos edukologijos universitetas
}

\begin{abstract}
Anotacija
Lietuvos Respublikos švietimo sistemą reglamentuojantys įstatymai gina kiekvieno asmens teisę igyti jo poreikius ir gebejimus atitinkantị išsilavinimą. Akcentuojama, kad privaloma mokykla prieinama visiems vaikams, nepaisant jų gebejjimų ir poreikių. Tad vienas esminių švietimo sistemos bruožų sudaryti sąlygas vaikams, turintiems raidos sutrikimų, mokytis pagal jų individualius gebėjimus atitinkančias programas, taikant specialiojo ugdymo mokomąsias priemones ir metodus, siekiant optimalios mokymosi kokybės. Todẻl pastaruoju metu atliekant įvairius tyrimus vis dažniau domimasi ịvairiais integruoto ugdymo proceso reiškiniais, atsiranda poreikis nagrinèti konkrečių dalyko pamokų tam tikrus sutrikimus turinčių mokinių integruoto ugdymo edukacinius sprendimus. Šiame straipsnyje atskleidžiami nežymiai sutrikusio intelekto mokinių edukaciniai ypatumai geografijos pamokose.

PAGRINDINIAI ŽODŽIAI: specialiųjų poreikių asmenys, specialieji ugdymosi poreikiai, nežymiai sutrikęs intelektas, integruotas ugdymas, mokymo ir mokymosi metodai, geografija.
\end{abstract}

\begin{abstract}
The laws regulating the educational system of the Republic of Lithuania guard the right of every person to receive eligible education meeting the needs and abilities of such persons. It is emphasised that the compulsory education should be accessible to all children irrespective of their abilities and needs. Thus one of the fundamental features of educational system is to create conditions for children with developmental disorders for learning according to programs adjusted to their needs and abilities and to seek optimal learning achievements by applying special teaching aids and methods. Many recent research works go deeper into various phenomena of integrated learning process. There is an obvious necessity to analyse the possible educational solutions for integrated learning of concrete subjects by students with various impairments. The present article deals with special aspects of teaching geography to students with mild intellectual disabilities.

KEYWORDS: persons with special needs, special learning needs, mild intellectual disability, integrated learning, learning and teaching methods, geography.
\end{abstract}

DOI: http://dx.doi.org/10.15181/tbb.v67i2.853

\section{Ivadas}

Lietuvos Respublikos švietimo sistemą reglamentuojantys įstatymai gina kiekvieno asmens teisę igyti jo poreikius ir gebejjimus atitinkantị išsilavinimą. Vienas esminių švietimo sistemos bruožų - sudaryti sąlygas vaikams, turintiems raidos sutrikimų, mokytis pagal jų individualius gebėjimus parengtas programas ir tai- 
kant specialiojo ugdymo mokomąsias priemones bei metodus, siekiant optimalios mokymosi kokybės (Ambrukaitis, 1996; 2013).

Šiuolaikinio visuomeninio gyvenimo praktika ir individuali žmogaus egzistencija atskleidžia vis didejančius jo biologinius ir socialinius prieštaravimus. Šis prieštaravimas visuomenès sąmonèje iškilo gana vèlai. Per visą žmonijos istoriją ị neịgalius asmenis žiūrèta iš aukšto, menkinant jų statusą visuomenèje, nekelti neiggaliujų gyvenimo ir švietimo klausimai. Tačiau jau 1959 m. paskelbta Vaiko teisių deklaracija dèl neiggalių vaikų gydymo ir ugdymo būtinumo. 1989 m. priimta Jungtinių Tautų Vaiko teisių konvencija, 1991 m. - Invalidų socialinès integracijos ịstatymas, 1996 m. - Lietuvos Respublikos Vaiko teisių apsaugos pagrindų įstatymas, 1998 m. - Specialiojo ugdymo įstatymas. 2000 m. - Dakaro konferencijos rezoliucija ir $2007 \mathrm{~m}$. - Neigaliujų teisių deklaracija - dar du dokumentai, kuriuos pasirašè ir įsipareigojo vykdyti Lietuva.

Visi šie įstatymai įtvirtina neiggalių vaikų ugdymą, atsižvelgiant ị jų galimybes. Jie nurodo pagrindinius mokyklos orientyrus, pabrēžia būtinybę puoselèti asmens dvasines ir fizines galias, padėti tvirtus dorovès ir sveikos gyvensenos pagrindus (Vilkelienè, 2003). Todèl dabar didžioji visuomenès dalis jau pripažịsta, kad mokiniai, turintys negalią, kaip ir jų bendraamžiai, besimokantys bendrojo lavinimo mokyklose, turi jausmų, tikslų, poreikių ir tam tikrų gebėjimų (Liaudanskiené, Viliūnienè, 2006). Lietuva, nuolat reformuodama švietimo sistemą ir būdama Europos Sajungos nare, diegia sutrikusios raidos vaikų ugdymo principą ir idejją: „Viena mokykla visiems." Akcentuojama, kad privaloma mokykla prieinama visiems vaikams, nepaisant jų gebejjimų ir poreikių. Tai patvirtina ir nuo 2011 metų įsigaliojęs Lietuvos Respublikos ịstatymas, kuriame teigiama, kad mokinių, kurie turi specialiujų ugdymosi poreikių, ugdymą igyvendina visos privalomaji ir visuotinị švietimą teikiančios mokyklos, kiti švietimo teikejjai, pavieniais atvejais - mokyklos (klasės), skirtos mokiniams, turintiems specialiujjų ugdymosi poreikių, ugdyti (LR švietimo ir mokslo ministro įsakymas, 2011). Todèl šiandien kiekvienas mokytojas turi užtikrinti moksleivių, kurie turi ypatingų poreikių, ugdymą bendrojo ugdymo mokykloje. Nauja mokymosi metodika (kaip metakognityviné didaktika) leidžia užtikrinti ir integruoti ị mokymąsi specialiųų ugdymosi poreikių turinčius vaikus, kartu su bendraamžiais skatindama ugdytis: gebejjimą mokytis, įsisąmoninti žinias, valdyti savo kognityvinius procesus (Kenneth Eklinth, 2003; cit. remiantis: Ambrukaitis, 2013). Tačiau negalima pamiršti, kad kol kas ši sudètinga sritis iki galo neatskleista ir nepriimta vieninga, patikimai veikianti metodika, kuri suvienytų dalykininko, specialiojo pedagogo ir ugdytinio darbą. O juk būtent mokyklos yra pagrindinė mokymosi vieta, siūlanti plačios apimties kokybišką individualią pagalbą organizuotu būdu. 
Siekdami užtikrinti ugdymo kokybę, ypač specialiujų poreikių turintiems mokiniams, mokytojai turi kruopščiai suplanuoti savo veiklą: parinkti tinkamus ugdymo būdus ir formas, mokymo(si) metodus ir mokymo priemones. Teoriniai ir empiriniai tyrimai rodo, kad šiandienos mokytojas turi būti ịvairiapusiškai išsilavinęs ir kompetentingas specialistas, atitinkantis šiuolaikinès demokratinès visuomenès ir nuolat besikeičiančio pasaulio kriterijus, nuolat savo veiklą refleksuojanti ir save tobulinanti asmenybė, užtikrinanti ugdymo proceso sklandumą ir kokybę (Subotkevičienè, Stanaitis, 2011). Kaip teigia R. Čiužas (2013), šiuolaikiniai mokytojui keliami reikalavimai sukuria iš esmès naują erdvę, kurioje jis turi imtis naujų, neịprastų vaidmenų. Kasdienė mokytojo veikla neįsivaizduojama be didaktinès kompetencijos - žinių, gebejjimų, vertybių ir asmens savybių, lemiančių veiksmingą ugdymą. Būtent ši kompetencija daro ịtaką mokinių mokymosi motyvacijai ir rezultatams, padeda kurti veiksmingas mokymosi strategijas, kurios skirtos integruotam ugdymui. Deja, tenka pripažinti, kad universalių patarimų organizuojant integruotas pamokas, kai mokomi ir specialiųų poreikių turintys mokiniai, nėra, turbūt ir negali būti. Nes kiekvienu konkrečiu atveju reikia turèti omenyje daugelị veiksnių: dalyką, mokinių amžių ir gebejjimus, klasės mikroklimatą, specialiujų poreikių turinčių vaikų sutrikimus, mokytojo patirtį, naujausių švietimo dokumentų nurodymus. Labai svarbu, kad visi pamokos dalyviai būtų aktyvūs, darbingi, siekiantys atlikti suplanuotas pamokos užduotis, pasitvirtinti laukiamus rezultatus. Visa tai atsiskleidžia ịvairių dalykų mokytojų parengtose ir pritaikytose ugdymo programose (Pritaikytų ir individualizuotų programų formos, 2011). Nemažai pagalbos kiekvienam mokytojui dalykininkui suteikia ir Pagrindinio ugdymo 5-10 klasių bendrujų programų pritaikymo rekomendacijos, skirtos menkų gebėjimų ir nežymaus sutrikusio intelekto mokinių ugdymui (2009), kasmetinės mokslinės praktinès konferencijos, kurių metu dalijamasi gerąa darbo su specialiujų poreikių turinčių mokinių patirtimi.

Tiek mokinių ugdymas(is), tiek specialiujų poreikių turinčių mokinių ugdymo(si) organizavimas - plati tema. Pastaruoju metu specialiujų poreikių turinčių asmenų ugdymo(si), profesinès ir vis didejjančios integracijos ị visuomenę galimybės yra daugelio Lietuvos ir užsienio (Hornby, 1999; Silva, Morgado, 2004; Kugelmass, Ainscow, 2004 ir kt.) mokslinių publikacijų objektas (Ališauskas, 2001; Ambrukaitis, Ruškus, 2002; Dabrišienè, Narkevičienè, 2002; Gevorgianienè ir kt., 2004; Galkienė, 2005; Survutaite, 2012; Giedriené, 2013; Jankevičienė, 2013 ir kt.). Pavyzdžiui, Lietuvoje dar tebediskutuojama apie sutrikusio intelekto vaikų ugdymo bendrojo lavinimo mokykloje pranašumus ir trūkumus. Daugiausia tyrinejjamos ugdymo dalyvių nuostatos dèl sutrikusio intelekto vaikų integracijos ir sunkumų, su kuriais susiduriama organizuojant šių vaikų ugdymo procesą. Gana 
dažnai pasigendama konkretesnių sutrikimų analizès, kuri atskleistų mokinio turimus gebejimus, būdingus elgesio ugdymo ịstaigoje ypatumus, mokymosi sunkumus, kuriuos reikia ịveikti ir darbo su tokiais vaikais metodikas, kurios padètu pedagogams organizuoti integruotą mokymą(si) skirtingų dalykų pamokose.

Todèl šiame straipsnyje, remiantis mokslinès literatūros analize ir straipsnio autorès darbo patirtimi, apžvelgiami nežymiai sutrikusio intelekto (arba nežymaus protinio atsilikimo) mokinių mokymo(si) edukaciniai ypatumai bei mokymo(si) metodai, kurie gali būti sẻkmingai pritaikyti geografijos pamokose dirbant su minètais mokiniais.

Suformulavus probleminius straipsnio teiginius, apibrèžiamas straipsnio objektas - nežymiai sutrikusio intelekto mokiniai.

Straipsnio tikslas: apžvelgti nežymiai sutrikusio intelekto mokinių edukacinius ypatumus geografijos pamokoje.

Uždaviniai:

- aptarti nežymiai sutrikusio intelekto mokinių edukacinius ypatumus;

- apžvelgti literatūros šaltinius, kuriuose nagrinèjamos specialiujų poreikių turinčių mokinių ugdymo galimybės geografijos pamokose;

- pateikti kai kuriuos mokymo(si) metodus, kurie padètų organizuoti nežymiai sutrikusio intelekto mokinių mokymą(si) geografijos pamokose.

Tyrimo metodai: mokslinès literatūros ir empirinių tyrimo rezultatų analizè.

\section{Nežymiai sutrikusio intelekto mokinių savybès}

Prieš pradedant analizuoti nežymiai sutrikusio intelekto mokinių edukacinius ypatumus geografijos pamokose, tikslinga prisiminti kai kurias svarbias sąvokas (specialiuju poreikiu turintys asmenys, specialieji ugdymosi poreikiai, specialiuju poreikiu turinčiu mokiniu ugdymas) bei išanalizuoti nežymaus sutrikusio intelekto sampratą ir ši sutrikimą turinčių mokinių savybes.

Specialiuju poreikiu turinčiais asmenimis vadinami suaugusieji ir vaikai, dèl igimtų ar ịgytų sutrikimų galintys ribotai dalyvauti ugdyme ir visuomenès gyvenime. Ugdymosi sunkumų gali kilti dèl sutrikusio intelekto, klausos, kalbos, regos, fizinių, emocinių ir elgesio, specifinių pažinimo ar kitų vaiko raidos sutrikimų. Sąvoka specialieji ugdymosi poreikiai (SUP) apibrèžiama kaip pagalbos ir paslaugu reikmè, atsirandanti dèl to, kad ugdymo ir saviugdos reikalavimai neatitinka specialiụjų poreikių turinčio asmens galimybių (Kenneth, Eklinth, 2003; cit. remiantis: Ambrukaitis, 2013).

Vartojant specialiuju poreikiu turinčiu mokiniu ugdymo sąvoką kalbama apie mokinius, kurie turi specialiujų ugdymosi poreikių (SUP). UNESCO (1994) speci- 
aliujjų poreikių mokinių ugdymą apibrèžè inkliuzinès švietimo sistemos kontekste kaip tam tikrą pedagoginę intervenciją (ugdymo proceso pritaikymą) ir pagalbą, teikiamą atsižvelgiant ị kiekvieno mokinio specialiuosius ugdymosi poreikius (Daugiakultūrè įvairovè ir specialiujų poreikių mokinių ugdymas, 2009).

Remiantis Pasaulio sveikatos apsaugos organizacijos duomenimis, pasaulyje gimsta apie $11 \%$ vaiku, kuriems diagnozuojami vystymosi trūkumai ar sutrikimai, iš jų $3 \%$-sutrikusio intelekto (SI). Nežymiai sutrikęs intelektas (lengvas protinis atsilikimas) nustatomas ịvertinus dviejų sričių gebejjimus - intelekto funkcionavimo ir adaptacijos ịgūdžius. Nežymiai sutrikęs intelektas pasireiškia daug silpnesniu už vidutini intelekto funkcionavimu: mokinių IQ intervalas yra tarp 50 ir 70 . Be to, riboti adaptaciniai igūdžiai, kurie būtini kiekvienam žmogui prisitaikant prie gyvenamosios aplinkos dviejų ar daugiau šių sričių: komunikavimo, savarankiškumo, gyvenimo šeimoje, socialinio dalyvavimo, kryptingumo siekiant tikslo, sveikatos priežiūros ar saugumo, problemų sprendimo, laisvalaikio, darbo. Dažniausiai neįmanoma nustatyti tikslios intelekto sutrikimo priežasties. Nežymiai sutrikusio intelekto vaikus specialistai neretai vadina turinčiais kultūros ir šeimos nulemtą protinį atsilikimą.

Dirbant su nežymiai sutrikusio intelekto mokiniais daug dėmesio reikia skirti mąstymo, pažintinių interesų ugdymui, kalbos raidai. Labiausiai sutrikusios paprastai būna šių mokinių loginio mąstymo operacijos: analizavimas, lyginimas, apibendrinimas, išvadų formulavimas. Jiems sunkiai sekasi matematika, gramatika. Kalbos raida sulètejusi, bet dauguma mokinių gali vartoti kalbą kasdienejje veikloje. Kalba skurdi, joje mažai apibendrinamujų žodžių. Dẻl mąstymo inertiškumo mokiniai negeba pritaikyti jau ịgytų žinių naujose, neịprastose situacijose. Dažniausiai vyrauja vaizdinis, o ne verbalinis suvokimas, todèl jiems perteikiamos akademinès žinios turètų būti glaudžiai siejamos su praktine veikla, gyvenimo patirtimi, iliustruojamos konkrečiais pavyzdžiais. Mokomają medžiagą geriau ịsimena dažnai ją kartodami. Svarbus vaizdumo taikymas ugdymo procese. Nežymiai sutrikusio intelekto mokiniai pasižymi valingos veiklos stoka, pajègūs organizuoti savo veiklą tik padedami suaugusiujų, tačiau vaikai geba dalyvauti tikslingoje veikloje, kai užduotys atitinka jų gebejjimus. Jie yra gana darbštūs, drausmingi, pareigingi, sielojasi dèl nesėkmių, džiaugiasi pasiekę gerų rezultatų (Stankutè, 2011).

Nežymiai sutrikusio intelekto mokinių pažintiniams gebėjimams ugdyti (pojūčiams, suvokimui, dèmesiui, kalbai, motorikai lavinti, valios, emocijų sričiai tobulinti) ypač svarbi praktinè veikla per pamokas ir popamokinèje veikloje. Jei ugdymo programos daro teigiamą poveikį, kai kurių, ypač lengvai sutrikusio intelekto žmonių, būklè laikui bėgant gali pagerèti, ir jie nebebus priskiriami sutrikusio intelekto kategorijai. Palanki emocinė ugdymo aplinka ir mąstymo stimuliavimas gali padèti šiems mokiniams lavintis mokymosi ir socialinès adaptacijos ịgūdžius, 
formuotis pozityvų savojo „Aš “ suvokimą, koreguoti sutrikimus, palengvinti socializaciją ir integraciją ị socialinį kultūrinị gyvenimą. Konkrečiam mokiniui dalis ar net daugelis šių ypatumų gali būti nebūdingi, nes mokinių specialieji poreikiai ir sutrikimai būna labai ịvairūs. Todèl individualizuojant ugdymą svarbu atsižvelgti ị kiekvieno konkretaus vaiko unikalumą, pažinti jo asmenybę, turèti žinių apie mokinio socialinę aplinką ir atitinkamai specialiujų poreikių grupei būdingus kognityvinius (suvokimo, dèmesio, atminties, mąstymo), kalbos, emocinius-socialinius gebejjimų ypatumus bei mokymosi sunkumus. Bendradarbiaujant su specialiaisiais pedagogais, psichologais nustatomas mokiniui reikalingos specialiosios pagalbos pobūdis, intensyvumas, aptariamas sutrikusių ịgūdžių lavinimo būtinumas, numatomos korekcinès lavinamosios užduotys (Pagrindinio ugdymo 5-10 klasių bendrujų programų pritaikymo rekomendacijos, 2009).

Anot A. Galkienės (2005), nežymų protinį atsilikimą turinčių mokinių mąstymo ypatumai - žemesnis pažintinių procesų funkcionavimo lygmuo - lemia nemenkus bendrojo ir individualizuoto turinio skirtumus. Tačiau ugdymo programos efektyvumą garantuoja bendrojo ir individualizuoto turinio dermè, kuri pasiekiama integruojant programas. Šių mokinių integruoto ugdymo pagrindas - klasės, kurioje jie mokosi, turinys, nors jų ugdymo tikslai siejami su savarankiško gyvenimo igūdžių ugdymu ir rengimu profesinei veiklai, kuri nereikalauja didelių intelektinių gebejjimų. Paprastai besivystantiems mokiniams formuluojamos abstraktesnio mąstymo reikalaujančios užduotys, mokoma operuoti bendresnèmis sąvokomis, kūrybiškai taikyti ịgytas žinias praktikoje. Tuo tarpu nežymų intelekto sutrikimą turinčių mokinių gebejjimų raidos pobūdis skatina konkretinti žinias, sieti jas su gyvenimo praktika.

Remiantis nežymiai sutrikusio intelekto mokinių savybių charakteristikomis, apibendrinant galima teigti, kad integruojant ugdymą ir dirbant kryptingai, nuosekliai, nustatant pasiekiamus tikslus bei aiškias sąsajas tarp socialinès aplinkos ir nežymiai sutrikusio intelekto mokinių gyvenimo patirties, parenkant jų poreikius ir gebejjimus atitinkančias užduotis, mokymo(si) metodus ir būdus, galima ịveikti sunkumus ir vystytis besimokant įvairių mokyklinių dalykų.

\section{Nežymiai sutrikusio intelekto mokinių integruoto geografijos ugdymo teoriniai aspektai}

Kaip parodè mokslinès literatūros analizè, pastaruoju metu nemažai dėmesio skiriama specialiųjų poreikių mokinių integracijai Lietuvos bendrojo lavinimo mokykloje. Kaip integruotas ugdymas suprantamas skirtingų veiklos galimybių ir gebejjimų turinčių asmenų susitikimas sistemingai pedagoginei veiklai, partneriškais pagrindais spręsti ugdymo ir ugdymosi tikslus (Bitinas, 2000). İvairiuose tyri- 
muose aptariami ne tik konceptualūs integracijos klausimai nuostatų ir vertybių aspektais, bet ir domimasi konkrečiais integruoto ugdymo proceso reiškiniais. Kitaip tariant, nagrinėjama ugdymo realybė: pedagogų kompetencija, ugdymo programų keitimas, mokymo metodikos, mokytojų požiūris ị besikeičiančią profesinę veiklą, pedagogų nuostatos ugdant specialiujjų poreikių turinčius vaikus, specialiụjų poreikių turinčių mokinių ugdymo proceso organizavimas ir programų kūrimas, kt. (Ališauskas, 2001; Ambrukaitis, Ruškus, 2002; Dabrišienè, Narkevičienė, 2002; Gevorgianienè ir kt., 2003; Galkienė, 2005; Survutaite, 2012; Giedrienė, 2013; Jankevičienè, 2013 ir kt.). Specialiujų poreikių turinčių vaikų integracija ị bendrojo lavinimo mokyklas literatūroje apibrěžiama kaip kaitos procesas, skatinantis kitaip žvelgti ị visą ugdomaji procesą: ugdytinį, ugdytoją, ugdymo priemones ir ugdymo turinį. Integracija demokratinèje visuomenèje suvokiama kaip natūralus negrižtamas reiškinys (Kišonienè, Rudzinskienè, 2007).

Tačiau Lietuvoje beveik nẻra duomenų apie nežymiai sutrikusio intelekto vaikų veiklos geografijos pamokose ypatumus integruotose klasėse, o užsienio šalių literatūra, skirta geografijos pamokų integracijos klausimams, šiame straipsnyje neanalizuota. Dar 1976 m. R. B. Kaffemanas parašè straipsni „Pirmieji pagalbinès mokyklos mokinių geografiniai vaizdiniai“. Jame autorius teigia, kad geografiniai vaizdiniai formuojasi priešmokykliniame vaiko amžiuje ir visoje jo veikloje. Tam didžiulę ịtaką daro ịvairūs popamokiniai užsièmimai, ekskursijos, skaitiniai. Visi šie užsièmimai skatina pažintinius vaiko procesus ir deda pagrindus ne tik geografijos žinioms, bet ir lavina mokinių kalbą bei mąstymą.

1977 m. R. B. Kaffemanas savo knygoje „Anomalių vaikų mokymas ir auklëjimas" rašo, kad dèl sudètingumo ir abstraktumo geografinę medžiagą specialiujų poreikių vaikai sunkiai suvokia. Vaikai turi įsiminti daug sudėtingų dalykų ir reiškinių, kurių pasekmès ir priežastys dažnai būna nutolusios laiko ir erdvės atžvilgiu. Žinių ir vaizdinių bendrumas lemia pedagoginio proceso struktūrą, dažniausiai jungiančius žodinius ir vaizdinius mokymo būdus. Būtent vaizdinius R. B. Kaffemanas laiko pagrindiniu metodu, kuris padeda lengviau įsisąmoninti geografinę medžiagą specialiujų poreikių turintiems vaikams, taip pat ir nežymiai sutrikusio intelekto.

1976 m. pasirodè dar vienas su geografija susijęs straipsnis - V. S. Likyj „Didaktiniai reikalavimai geografijos pamokoms, organizuojant savarankišką mokinių darbą“. Šiame straipsnyje nagrinèta, kaip turètų dirbti specialiujų poreikių turintys mokiniai per geografijos pamokas (cit. Remiantis: Antonoviené, 1996). Jame autorius teigia, kad didelis demesys turi būti skiriamas teisingam savarankiškos mokinių veiklos organizavimui, tai padètų reguliuoti specialiụjų poreikių turinčių vaikų mąstymo, atminties ir dėmesio sulaikymo procesus, skatintų jų pasitikèjimą savo jègomis. 
Apie praktinès veiklos naudą geografijos pamokose specialiojoje mokykloje rašo L. S. Liubišina (1990) straipsnyje „Praktinès veiklos kryptys geografijos pamokose pagalbinèje mokykloje“ (cit. Remiantis: Antonovienė, 1996). Autoré teigia, kad geografijos pamokose yra daug įvairių praktinès veiklos galimybių. Specialiųjų poreikių turinčių, kaip ir nežymaus sutrikusio intelekto, mokinių žinių kokybè, mokejjimai bei ịgūdžiai atliekant praktinę veiklą priklauso nuo pamokos organizavimo. Praktinis darbas gali būti naudojamas visose pamokose, tik reikia ji gerai apmąstyti, įvertinti realias mokinių galimybes ir turimą žinių kiekị. Užduotys nežymaus sutrikusio intelekto vaikams turi būti aiškiai ir tiksliai suformuluotos. Populiariausios mokinių praktinès veiklos priemonès yra kontūriniai žemėlapiai, objektų atkūrimas piešiant.

Apie žemėlapio reikšmę mokant geografijos specialiųjų poreikių turinčius vaikus rašè V. Antonovienė (1996) straipsnyje „Žemèlapio reikšmè geografijos pamokose specialiojoje mokykloje“. Autorès teigimu, stebèti reiškinius, mintyse analizuoti geografijos faktus ir vaizdžiai juos nusakyti specialiujų poreikių turintiems vaikams labai sudètinga. Planuojant darbą svarbu atsižvelgti į kiekvieno vaiko galimybes, individualias jo ypatybes, tai padès suplanuoti mokomosios medžiagos pateikimą taip, kad vaikui ji būtų lengviau suprantama ir greičiau išmokstama. V. Antanovienè teigia, kad diferencijuotas ir individualus darbas pamokoje skatina mokytoją atsižvelgti ị kiekvieno vaiko teigiamas ir neigiamas savybes, būti kantriam ir geranoriškam skatinant domètis savo mokomu dalyku.

1998 metais J. Pumputis knygoje „Specialusis ugdymas I“ pateikè straipsni „Specialiosios mokyklos VII-IX klasių mokinių žinios apie Lietuvos paviršių ir naudingąsias iškasenas“. Juo autorius siekia išsiaiškinti specialiosios mokyklos VII-IX klasių mokinių žinias apie Lietuvos paviršių ir naudingąsias iškasenas. Atlikus tyrimą paaiškejjo, kad ketvirtadalio mokinių žinios apie Lietuvos geografiją yra neblogos. Dar ketvirtadalis supranta, apie ką kalbama, tačiau išsamiai atsakyti ị klausimą negali. Straipsnyje taip pat akcentuojama vaizdumo geografijos pamokose reikšmè. Iliustracinès priemonès turètų būti derinamos visose pamokos dalyse. Pasak, J. Pumpučio, mokinių darbas per tyrimą, mokytojų atsiliepimai, asmeniški pastebėjimai rodo, kad specialiuju poreikių turintys, taip pat nežymiai sutrikusio intelekto, vaikai gali išmokti geografiją, tik jiems reikia padèti.

Kalbant apie integruotą geografijos ugdymą, galima paminèti kelis geografijos vadovėlius, skirtus darbui su specialiujų poreikių turinčiais mokiniais. Šių priemonių tikslas - sudaryti kuo palankesnes sąlygas specialiujų poreikių mokiniams ugdytis kartu su bendraamžiais bei palengvinti mokytojo darbą klasejje. Tokio pobūdžio mokomujų priemonių labai reikia, nes jų yra nedaug, o negausios esamos jau šiek tiek pasenusios (pvz., J. Zagorskio ir V. Kontvainienès „Lietuvos geografijos vadovèlis 9 klasei““ [2000]). Tik $2011 \mathrm{~m}$. pasirodè nauja mokomoji knyga 
„Geografija 8 klasei“ (S. Dijokienè, A. Brazienè, L. Martišiūtè). Ji pritaikyta ir skiriama mokiniams, turintiems specialiujų ugdymosi poreikių bei tinka nežymiai sutrikusio intelekto mokiniams. Vadovèlis parengtas vadovaujantis Bendrosiomis ugdymo programomis (2009).

Taigi literatūros analizė atskleidè, kad šaltinių ir mokslinių tyrimų, kurie būtų susiję su nežymiai sutrikusio intelekto vaikų integracija ar mokymo(si) ypatumais, Lietuvos bendrojo lavinimo mokyklose (geografijos pamokose) beveik neatlikta. Negausus ir mokymo priemonių sąrašas. Išanalizuoti siūlymai dažniausiai pasenę ir skirti specialiųjų poreikių turintiems mokiniams, kurie mokosi specialiose mokyklose. Todèl šio skyriaus išvados tik patvirtina straipsnio aktualumą.

\section{Kai kurie mokymo(si) metodai, padedantys ugdyti nežymiai sutrikusio intelekto mokinius geografijos pamokose}

Remiantis šio straipsnio pirmos dalies išvada, kad dirbant kryptingai ir nuosekliai, nustatant pasiekiamus tikslus bei aiškias sąsajas tarp socialinès aplinkos ir nežymiai sutrikusio intelekto mokinių gyvenimo patirties, parenkant jų poreikius ir gebejjimus atitinkančias užduotis, mokymo(si) metodus ir būdus, galima įveikti vystymosi sunkumus besimokant ịvairių mokyklinių dalykų. Remiantis nežymiai sutrikusio intelekto mokinių mokymo(si) ypatumų geografijos pamokose tyrimų stoka, iškyla būtinybė apžvelgti tam tikrus mokymo(si) metodus, kuriuos galima sėkmingai taikyti dirbant integruotose geografijos pamokose su nežymiai sutrikusio intelekto mokiniais.

Bendrieji nežymiai sutrikusio intelekto mokinių ugdymo tikslai: ugdyti asmenines, socialines, kultūrines kompetencijas, suteikti pilietiškumo pradmenis, lavinti savarankiško gyvenimo ịgūdžius, suteikti elementarų bendrajj raštingumą, rengti mokinius įgyti profesiją ir naudotis tęstinio ugdymo galimybėmis pagal jų gebejjimams pritaikytą profesinio arba vidurinio ugdymo programą (Pagrindinio ugdymo 5-10 klasių bendrųų programų pritaikymo rekomendacijos, 2009).

Geografija - tai mokslų sistema, apimanti gamtos ir visuomenès mokslų šakas, kurios tiria gamtinius ir gamybinius-teritorinius kompleksus bei jų komponentus. Tai vienas labiausiai integruotų mokomųjų dalykų mokykloje. Geografija atskleidžia mozaikiško pasaulio gamtos ir visuomenès vientisumą, erdvines civilizacijų ir kultūrų sąsajas, gamtos ir visuomenès savitarpio priklausomybę, jų raidos ir išlikimo klausimus. Ugdomos asmens nuostatos skatina solidarumą, rezultatyvų kultūrų dialogą ir tarptautinị bendradarbiavimą, padeda plètoti visų rasių, tautų, religijų bendruomenių tarpusavio supratimą, skatina toleranciją ir draugystę, siekị konstruktyviai spręsti kylančias vietos bendruomenių, šalių, pasaulio problemas. Puo- 
selëjamas mokinių nusiteikimas ir gebejimas kompetentingai naudotis geografijos žiniomis bei ịūdžiais asmeniniame, profesiniame ir visuomeniniame gyvenime (Bendrosios programos, 2009). Geografija - sudètinga mokslų sistema, apimanti daugelị šakų ir kurianti integruotą visuminị mokslinį pasaulio vaizdinį, grindžiamą erdviniais ryšiais ir jų kaita.

Bendrosiose programose (2009) keliamas toks geografijos ugdymo tikslas: plètoti mokinių geografinị pasaulèvaizdị, skatinti domètis savo ir kitų šalių gamtos bei visuomenès įvairove, plèsti geografijos žinias ir supratimą, padèti ugdytis socialinę kompetenciją. Siekdami geografijos dalyko tikslo, mokiniai mokosi orientuotis gamtinėje ir visuomeninėje aplinkoje, naudoja kartografinius kūrinius, kaip patikimus informacijos šaltinius, renka ir analizuoja įvairiuose informaciniuose šaltiniuose pateikiamą informaciją, kritiškai ją vertina, domisi Lietuvos ir kitų šalių gamtos bei visuomenès ịvairove, ịvairia geografine veikla, aktyviai tiria savo ir kitų kraštų gamtinę bei visuomeninę aplinką, susipažista su ja. Ugdymo procese integruojamos šios veiklos sritys: orientavimasis erdvejje ir žemėlapyje, geografinès informacijos skaitymas, regionų pažinimo raiška, aplinkos pažinimas ir tyrimai. Atsižvelgiant ị mokinio patirti, žinias ir gebejjimus, geografijos supratimą, kiekvieno koncentro turinys nagrinejjamas lokalioje, regiono ir globalioje geografinèje erdvejje (Bendrosios programos, 2009).

Taigi geografija nežymiai sutrikusio intelekto mokiniams padeda susikurti geografinị pasaulèvaizdị, skatina domètis savo ir kitų šalių gamtos bei visuomenès ịvairove, formuoti pozityvų jų požiūrị i supančią aplinką, saugų elgesị gamtinèje ir visuomeninėje aplinkoje. Igyvendinant šị tikslą, dalyko mokytojams reikètų kurti tokias mokymosi strategijas, kurios leistų šių sutrikimų turinčius mokinius išmokyti mokytis, būti kuo savarankiškesniais, planuoti laiką, lavinti skaitymo, klausymo, praktinių darbų atlikimo bei savo darbo vertinimo gebejjimus. Paprastai didžioji dalis minètų mokymosi strategijų efektyvumo priklauso nuo tinkamai parinktų ir geografijos pamokose taikomų mokymo(si) metodų.

Kiekvieno metodo tikslas - tam tikro gebejjimo ugdymas ir (arba) būtinų žinių suteikimas. Remiantis L. Šiaučiukéniene ir kt. (2006; 2011), mokant galima taikyti tiek pasyvius, tiek aktyvius metodus. Aktyvūs metodai susiję su mokinių savarankišku darbu, pasyvūs - su informacijos suvokimu (aiškinimas, pasakojimas), kas ypač aktualu nežymaus protinio atsilikimo mokiniams.

Taigi, siekiant integruoti nežymiai sutrikusio intelekto mokinius geografijos pamokose, svarbu atsižvelgti ị mokinių individualias galimybes, mokytojo kompetenciją, integruojamos klasès lygị, mikroklimatą, dalyko turinį, temos sudètingumą, esamų priemonių kokybę, remtis bendrosiomis programomis, praktinėmis rekomendacijomis ir pan. Todėl organizuojant integruotą ugdymą, kartais gana sudètinga parinkti tinkamus mokymo(si) metodus. Tad šios straipsnio dalies tikslas, 
remiantis moksline literatūra bei autorès patirtimi, apžvelgti tik kai kuriuos integruotose geografijos pamokose taikomus mokymosi metodus, kurie leidžia gana efektyviai dirbti su nežymiai sutrikusio intelekto mokiniais. Straipsnyje remiamasi L. Šiaučiukėnienès (2011) pateikiama mokymo ir mokymosi metodų klasifikacija, bet akcentuojami mokymosi metodai, nes būtent jie padeda ugdyti mokinių savarankiškumą, aktyvumą, kūrybiškumą, gebėjimus priimti sprendimus. Tai aktualu ir tam tikrų sutrikimų turintiems mokiniams.

Taip pat svarbu paminèti, kad universalių patarimų, kaip ir gerų, tobulų ar blogų metodų, negali būti. Mokiniai skirtingi, todèl ne visi mokymosi metodai visiems vienodai tinka, net ir turintiems vienodą sutrikimą. L. Šiaučiukènienès ir bendraautorių (2006) teigimu, ,geri“ metodai yra tie, kuriu dęka atsiskleidžia esminis jų komponentas - išmokimas. Ivairiai pamokose derinamais metodais siekiama pakartoti ir ịtvirtinti svarbiausią medžiagą, naujus žodžius ir sąvokas, atskleisti ịvairiapusiškus aplinkos, gamtos ir visuomenès objektų bei ịvairių reiškinių ryšius ir priklausomybę.

Konstruojant ir planuojant integruotas geografijos pamokas, kuriose mokosi nežymiai sutrikusio intelekto mokiniai, galima taikyti klasikinius informacijos šaltinių naudojimo, praktinius operacinius ir kūrybinius mokymosi metodus, tad tikslinga kai kuriuos apžvelgti detaliau.

Geografijos objektų lyginimas - tai metodas, kuris tinka objektų esminiams požymiams išskirti, nurodant panašius ir skirtingus požymius. Dirbant su sutrikusio intelekto mokiniais objektus tikslingiausia pradèti lyginti surandant skirtumus, nes mokiniai tai lengviau supranta, tada pereiti prie panašumų atskleidimo. Iš pradžiu geriausia būtų lyginti ne daugiau kaip du objektus, pvz., dvi klimatogramas - Kauno ir Vilniaus). Galima palyginti temperatūrų ir kritulių skirtumus.

Mokinių pasakojimas pagal planą. Pasakojimo planą, sudarytą iš kelių (3-4) struktūrinių dalių, užrašome sąsiuvinyje arba kortelèje, kad vaikams būtų lengviau orientuotis, ką pasakoti. Mokytojas klausimais gali siekti susisteminti medžiagą, nusakyti objekto ar reiškinio reikšmę žmogui, padaryti išvadą, priskirti objektą ar reiškinị tam tikrai daiktų ar reiškinių grupei, pvz., papasakoti apie Lietuvos augaliją, klimato poveikị žmogaus gyvenimui ir pan.

Geografinių mịslių minimas ir kitos smulkiosios liaudies tautosakos taikymas. Mịslių tematika labai ịvairi: negyvosios gamtos daiktai, reiškiniai, žmogus ir pan. Mịslès tematika ir turinys labai skirtingi, bet jų esmė yra vieninga - tai loginis uždavinys. Iminti mịslę, vadinasi, surasti uždavinio sprendimą, t. y. atlikti gana sudètingas mąstymo operacijas. Mįslių minimas sutrikusio intelekto mokiniams yra sudètingas darbas. Supažindinimas su aplinkos, gamtos, visuomeniniais objektais ir reiškiniais sudaro mịslių turinio atskleidimo pagrindą. Dažniausiai mịsles minsime ne prieš supažindindami su nauja medžiaga, o jau 
susipažinus su ja. Mịslių minimas ugdo vaikų gebėjimą analizuoti, sisteminti, apibendrinti, daryti išvadas.

Naujų geografijos sąvokų ịtvirtinimas. Čia galima taikyti ịvairius būdus, pvz., parinkti epitetus, antonimus, sinonimus, remiantis vaizdine medžiaga. Svarbu, kad mokiniai būtų ne tik supažindinami su naujais žodžiais, bet ir ịvairiapusiškai atskleista jų prasmè, taigi jie turi būti pakartoti ir įtvirtinti, pavartoti rišlioje kalboje. Imant bet kurią temą iš teksto išrašomos svarbiausios sąvokos ir prašoma jas paaiškinti remiantis tekstu. Tada ịtvirtinti pavyzdžiais iš gyvenimo, pvz., analizuojant ịvairias paviršiaus formas (kalva, duobė, kalnas, žemuma ir t. t.), kalbant apie orus ir orų prognozes, upes, ežerus ir pan.

Sakinių papildymas. Paruošiame korteles, kuriose praleisti pavieniai žodžiai (atsižvelgiant ị ịvairią nagrinètą medžiagą). Mokiniams paaiškinama užduotis. Atliekama raštu. Sakiniai gali būti ne tik apibūdinamieji, bet ir apibendrinamieji. Tikslinga sudaryti stilistiškai įvairius sakinius. Pvz., nesudètingai apibūdinama naudinga medžiaga ir jos panaudojimas. Taip pat tinka ịvairiems gamtoje vykstantiems reiškiniam apibūdinti (pvz., lietus, žemès drebejjimas ir pan.).

Lentelių pildymas. Ittvirtinant medžiagą, toks darbas sudomina ir mobilizuoja mokinius. Pildyti lenteles patartina sąsiuviniuose, derinant su vaizdiniais metodais ir be jų. Pvz., užpildyti pasirinkto mėnesio orų lentelę.

Nesudètingų geografinių kryžiažodžių sprendimas. Pirmieji kryžiažodžiai sudaromi labai paprasti, nedidelès apimties, iš vienoje ar keliose pamokose nagrinètų dalykų. Pakanka išdèstyti tik horizontalias kryžiažodžio juostas. Apibūdinimą galima pateikti mokytojo apibūdintų mịslių forma. Kryžiažodžio taisyklès turi būti išaiškintos labai nuosekliai, paprastai, lakoniškai, kad mokiniai suprastų, ko iš jų norima. Sprendžiant kryžiažodị, pakartojama medžiaga, lavinamas vaikų mąstymas, svarbiausia, kad mokiniams tai labai patinka.

Schemų pildymas. Sutrikusio intelekto mokiniams gali būti pateikiamos schemos. Jos turètų būti nesudètingos, lengvai suprantamos ir užpildomos. Reikia labai rūpestingai parinkti jų turini, kad kartu sistemintume mokinių žinias. Pvz., parašomas pramonės šakos pavadinimas, o ịvairių gaminių pavadinimus mokiniai ịrašo patys.

Gamtos objektų ir žmogaus sukurtų daiktų atpažinimas ir pavadinimas (panaudojant tiek natūralius objektus, tiek daiktus, vaizduojančius vaizdines mokymo priemones). Šis būdas reikšmingas tuo, kad glaudžiai siejasi žodis, vaizdas ir praktine veikla. Tai sutrikusio intelekto vaikui labai svarbu. Pvz., atpažinti debesų rūšis, paviršiaus formas ir pan.

Integruotose geografijos pamokose, dirbant su nežymiai sutrikusio intelekto mokiniais, gali būti taikomi ir įvairūs kūrybiniai metodai, pvz., „Kviečiame keliauti po Europą“, „Lietuvos regionai ir lankytinos vietos“, „Kaip aš pažįstu Vil- 
nių“ ir pan. Kai mokiniai dirba su žemélapiais, sudarinėja ir aprašinejja tam tikrus objektus, jie aktyviai naudoja įvairius šaltinius, pasitelkia informacines technologijas, susidomi geografija, gauna teigiamų emocijų, ugdosi savarankiškumą.

Dar vienas kūrybinis metodas, padedantis susidaryti tinkamus vaizdinius, yra geografijos objektų modelių kūrimas. Jị taikant ypač gerai ịsimenami esminiai objektų požymiai. Paprastai mokytojas, demonstruodamas geografijos objektą, pats jị apibūdina, nurodo jo savybes ir aptaria tų savybių santykius. Demonstruojamas objektas tik patvirtina arba sukonkretina tai, kas aiškinama žodžiu. Gerokai naudingiau, kai patys mokiniai atitinkamą objektą sumodeliuoja, patys išskiria ir nurodo būdingus požymius, juos lygina, grupuoja. Tai gera korekcinė priemone mokiniams, nes įtraukiami klausos ir regejjimo analizatoriai, smulkioji motorika, aktyvinamas žodynas. Tikslesnis tampa grafinis vaizdavimas, pagerèja vaizdinių kokybè. Modeliuojant reikètų stengtis laikytis tikslių proporcijų, kad mokiniai nesusidarytų klaidingų vaizdinių.

Geografijos mokymasis ypač turtina mokinių vaizdinių ir sąvokų pasaulį. Tačiau nereikia pamiršti, kad nežymiai sutrikusio intelekto mokinių suvokimas, mąstymas, atmintis, vaizduote turi tam tikrų ypatumų: negebejimas atpažinti daiktų, surasti jų esminius ir neesminius požymius, ịsivaizduoti nagrinėjamus objektus, atsiminti jų panašumus ir skirtumus, nustatyti priežasties ir padarinių ryšius. Dèl to negebama apibendrinti ir nuo vaizdinių pereiti prie sąvokų. Literatūros analizė ir praktika atskleidè, kad vaizdinių kūrimas nežymiai sutrikusio intelekto vaikams taip pat yra gana sudètingas procesas. Tradiciniai geografinių vaizdinių kūrimo būdai, kurie remiasi verbaliniu vizualiniu suvokimu, dažnai neduoda teigiamų rezultatų. Mokytojams nuolat tenka ieškoti naujovių, kurios padètų sudaryti tinkamus, visaverčius geografinius vaizdinius. Labai dažnai padeda šiuolaikiniai mokymosi metodai. Vienas jų - „piešimas ore“. Iprasta, kad žemesnių klasių mokiniai, mokydamiesi naują raidę ar skaičių, jų elementus pirštu „piešia“ ore. Taikant ši principą, šeštos klasès mokiniai gana gerai išmoksta grafiškai pavaizduoti Žemės paviršiaus formas ir kai kuriuos vandens telkinius. Pagerẻja jų vaizdinė kokybė: jie tampa ịvairesni, plastiškesni. Mokytojas, taikydamas euristinị pokalbị, išsiaiškina, ką mokiniai žino apie atitinkamą Žemès paviršiaus formą, palygina ją su artimiausioje aplinkoje esančia, aiškindamas naują medžiagą, demonstruoja paveikslus, lygina juos tarpusavyje. Tada jau galima patiems bandyti pavaizduoti tai, ką matè, sužinojo. Pavyzdžiui, Žemès paviršiaus forma - lyguma.

Nagrinejjant vandens telkinius, šis būdas pasiteisina, kai norima išmokti grafiškai pavaizduoti ir palyginti ežerą bei upę. Pirštu ,piešiame“ ore ežero kontūrus, garsiai komentuojame. Po to „piešiame“ upę, ją taip pat komentuojame. Mokinys nebijo „piešdamas“ suklysti, nes tai, ką jis „piešia“, mato tik mokytojas, kuris visada pasirengęs padèti. Tada jau galima piešti sąsiuviniuose. Ir čia galima leisti 
mokiniams improvizuoti, papildomai nupiešti neesminių detalių: žuvis, nendres, valtị ir t. t. Taip vienu metu susidaro grafinis objekto vaizdinys, turtinamas aktyvusis žodynas, tobulèja smulkioji motorika.

Integruotoms geografijos pamokoms puikiai tinka dar viena aktyvių mokymosi metodų grupe - ịvairūs didaktiniai žaidimai, pvz., ,kas greičiau suras 5 ilgiausias upes“, žaidimas „taip arba ne“ ir t. t. Jie svarbūs skatinant nežymiai sutrikusio intelekto mokinių mokymo efektyvumą, nes turi korekcinę auklèjamąją reikšmę. Per pamoką žaisdami didaktinius žaidimus mokiniai ne tik susistemina ir įtvirtina žinias, bet ir susikuria vaizdinius. Toks mokymo procesas tampa įdomesnis, patrauklesnis, igalinantis ịveikti sunkumus. Žaisdami mokiniai atlieka užduotis,

kurios atrodo nepatrauklios ir sunkios. Žaidimai padeda sukaupti dèmesị, valią, mokiniai padeda vienas kitam, pasitikrina žinias, kartu padidèja domejjimasis geografija kaip dalyku (Pumputis, 2002).

Nežymiai sutrikusio intelekto mokiniams galima taikyti ịvairius bendradarbiavimo mokymosi metodus, pvz., grupinio darbo, abipusio mokymo, „sakyk ir klausyk" ir pan. Taikant pastaruosius metodus mokiniai net tik turi galimybę mokytis kartu su kitais, bet ir jaučiasi esą visaverčiai klasės nariai.

Konstruojant integruotas geografijos pamokas, kuriose mokosi nežymiai sutrikusio intelekto mokiniai, galima sudaryti nemažą tinkamų mokymosi metodų sąrašą. Tačiau, L. Šiaučiukènienès ir bendraautoriu (2006) teigimu, nereikia pamiršti, kad visi jie turi ne tik privalumų, bet ir trukumų. Todèl lemiamą vaidmenị vaidina ne tik mokinio sutrikimas, bet ir mokytojo asmenybè, gebejjimas parinkti adekvačius mokymo(si) tikslui bei mokinio mokymosi stiliui metodus, kurie igalintų bet kokio lygio mokinị mokytis. Šioje situacijoje vienodų, šabloniškų patarimų negali būti, todèl drąsiai galima teigti, kad integruotų geografijos pamokų, kuriose mokosi nežymiai sutrikusio intelekto mokiniai, organizavimas yra geografijos mokytojo meistriškumo ir kompetencijos išbadymas.

\section{Išvados}

1. Nežymiai sutrikusio intelekto mokinių paprastai labiausiai sutrikusios būna šios loginio mąstymo operacijos: analizavimas, lyginimas, apibendrinimas, išvadų formulavimas, suletejusi kalbos raida, mokiniai negeba pritaikyti jau ịgytu žinių naujose, neịprastose situacijose, dažniausiai vyrauja vaizdinis, o ne verbalinis suvokimas, todèl jiems perteikiamos akademinės žinios turètų būti glaudžiai siejamos su praktine veikla, gyvenimo patirtimi, iliustruojamos konkrečiais pavyzdžiais, pasižymi valingos veiklos stoka, pajègūs organizuoti savo veiklą tik padedami suaugusiujų. Ta- 
čiau dirbant kryptingai, nuosekliai, nustatant pasiekiamus tikslus ir aiškias sąsajas tarp socialinės aplinkos ir nežymiai sutrikusio intelekto mokinių gyvenimo patirties, parenkant jų poreikius ir gebejimus atitinkančias užduotis, mokymo(si) metodus ir būdus, galima ịveikti sunkumus ir siekti galimybès vystytis besimokant ịvairių mokyklinių dalykų.

2. Pastaraji dešimtmeti nemažai dèmesio skiriama specialiujų poreikių (taip pat ir nežymiai sutrikusio intelekto) mokinių integracijai Lietuvos bendrojo lavinimo mokyklose. Ivairiuose tyrimuose jau aptariami ne tik konceptualūs integracijos klausimai nuostatų ir vertybių aspektu, bet ir gilinamasi ị konkrečius integruoto ugdymo proceso reiškinius: pedagogų kompetenciją, ugdymo programų keitimą, mokymo metodikas, mokytojų požiūrị i besikeičiančią profesinę veiklą, specialiujų poreikių mokinių ugdymo proceso organizavimą ir kt. Tačiau literatūros analizè atskleidè, kad nežymiai sutrikusio intelekto vaikų edukaciniai ypatumai geografijos pamokose tebėra aktuali Lietuvos bendrojo lavinimo mokyklų ir pedagogų problema, nes negausūs literatūros šaltiniai dažniausiai yra pasenę, o pateikti siūlymai skirti mokiniams, besimokantiems specialiose mokyklose.

3. Geografija nežymiai sutrikusio intelekto mokiniams padeda ugdytis geografini pasaulèvaizdị, skatina domètis savo ir kitų šalių gamtos bei visuomenès įvairove, formuoja pozityvų jų požiūrị ị supančią aplinką, saugų elgesị gamtinèje ir visuomeninèje aplinkoje. Igyvendinant ši tikslą, dalyko mokytojams reikia siekti kurti tokias mokymosi strategijas, kurios padètu šių sutrikimų turinčius mokinius išmokyti mokytis, būti savarankiškesniais, planuoti laiką, lavinti skaitymo, klausymo, praktinių darbų atlikimo bei savo darbo vertinimo gebẻjimus. Dažniausiai didžioji dalis minètų mokymosi strategijų efektyvumo priklauso nuo tinkamai parinktu ir geografijos pamokose taikomų mokymo(si) metodų.

4. Planuojant ir konstruojant integruotas geografijos pamokas, kuriose mokosi nežymiai sutrikusio intelekto mokiniai, galima taikyti klasikinius informacijos šaltinių naudojimo, praktinius operacinius ir kūrybinius mokymosi metodus (pasakojimas pagal planą, schemų pildymas, ịvairių objektų atpažinimas, geografinių modelių kūrimas ir t. t.). Labai dažnai ugdyti nežymiai sutrikusio intelekto mokinius padeda įvairūs šiuolaikiniai mokymosi metodai: ,piešimas ore“, didaktiniai žaidimai, grupinis darbas, abipusis mokymas ir t. t. Pasirenkant mokymosi metodus, svarbu pabrèžti, kad bendrų patarimų negali būti, lemiamą vaidmenį vaidina ne tik mokinio sutrikimas, bet ir mokytojo asmenybė, gebéjimas parinkti adekvačius mokymo(si) tikslui ir mokinio mokymosi stiliui metodus, kurie igalintu mokytis bet kokio lygio mokinị. Integruotu geografijos pamokų, kuriose 


\title{
mokosi nežymiai sutrikusio intelekto mokiniai, organizavimas ir tinkamų metodų parinkimas yra geografijos mokytojo meistriškumo ir kompeten- cijos išbadymas.
}

\author{
Gauta 20140106 \\ Pasirašyta spaudai 20140701
}

\section{Literatūra}

Ališauskas, A. (2001). Specialiųjų ugdymosi poreikių tenkinimas bendrojo lavinimo mokyklose: pokyčių analizè. Specialiuju poreikiu vaiku pažinimas ir ugdymas. Šiauliai, p. 6-11.

Ališauskas, A. (1996). Vaikų vystymosi ypatingumu pažinimas ir ịvertinimas. Šiaulių pedagoginis universitetas.

Ambrukaitis, J. (2013). Žemu intelektiniu gebejjimu mokiniu ugdymas pagal adaptuota bendraja programą: tèvu ir mokytojų knyga. Šiauliai: Liucijus.

Ambrukaitis, J., Ruškus, J. (2002). Adaptuotos bei modifikuotos ugdymo programos: taikymo efektyvumo veiksniai. Specialusis ugdymas, nr. 2 (7): 6-23.

Antonovienė, V. (1996). Žemėlapio reikšmė geografijos pamokose specialiojoje mokykloje. Vaiku, turinčiu specialiuju poreikiu ir suaugusių neigaliu asmenu socializacija: mokslinès praktinès konferencijos medžiaga. Šiaulių universiteto leidykla, p. 127-129.

Bitinas, B. (2000). Ugdymo filosofija. Vilnius: Enciklopedija.

Čiužas, R. (2013). Mokytojo kompetencijos. Profesinio meistriškumo siekis. Vilnius: Edukologija.

Dabrišienè, V., Narkevičienè, B. (2002). Individualizuoto ugdymo programų specialiujų poreikių moksleiviams sudarymo principai: teorinis pagrindimas. Specialusis ugdymas, nr. 2 (7): 24-30.

Daugiakultūrè ịvairove ir specialiuju poreikiu mokiniu ugdymas, Europos specialiojo ugdymo plètros agentūra. Ataskaita. (2009). Prieiga internete: http://www.european-agency.org/sites/default/files/multicultural-diversity-and-special-needs-education_Multicultural-Diversity-LT.pdf [2014 01 13].

Dijokienė, S., Brazienè, A., Martišiūtè, L. (2011). Geografija 8 kl.: mokomoji knyga. Kaunas: Šviesa.

Galkienè, A. (2005). Heterogeniniu grupių didaktika. Šiaulių universitetas.

Gevorgianienė, V., Trečiokaitė, G., Zaikauskas, V. (2004). Skirtingai ugdomų nežymiai sutrikusio intelekto moksleivių akademinių ir socialinių gebėjimų lyginamoji analizè. Specialusis ugdymas, nr. 1(10): 98-108.

Gevorgianienė, V., Zaikauskas, V. (2007). Skirtingo tipo mokyklų nežymiai sutrikusio intelekto mokinių akademiniai pasiekimai. Acta Pedagogica Vilnensia, p. 158-169.

Giedrienè, R. (2013). Specifiniai mokymosi sutrikimai ir vaiko socializacija. Vilnius: Edukologija.

Hornby, G. (1999). Inclusion or delusion: can one size fit all? Suport for learning, vol. 14, no 4: 15-24.

Jankevičienė, L. (2013). Specialiųų ugdymosi poreikių turinčių vaikų integracija ị bendrojo lavinimo mokyklą: būsimųjų pedagogų požiūris. Socialiniai mokslai. Edukologija. Jaunujų mokslininkų darbai, nr. 1 (39): 32-38.

Kišonienė, R., Rudzinskienė, R., (2007). Mokinių, turinčiu specialiujų ugdymo(si) poreikiu, ugdymo turinio individualizavimas. Rekomendacijos mokytojams, ugdantiems skirtingu poreikiu ir gebejjimu mokinius. Vilnius: VIA RECTA.

Koffemanas, R. (1977). Pagalbinès mokyklos mokiniu geografinių žinių ir vaizdiniu formavimo psichologiniai ypatumai. Anomaliu vaiku mokymas ir auklejimas, Vilnius, p. 60-67.

Koffemanas, R. (2005). Riboto ir nežymiai sutrikusio intelekto moksleivių kognityvinių gebèjimų ypatumai. Specialusis ugdymas, nr. 1(12): 50-60.

Kontvainienè, V., Zagorskis, J. (2000). Lietuvos geografija: vadovèlis IX kl. (spec. por. mok.). Vilnius: Danielius.

Kugelmass, J., Ainscow, M. (2004). Leadership for inclusion: a comparison of international practices Journal of research in special educational needs, vol. 4, no. 3: 133-141. 
Liaudanskienè, V., Viliūnienè, A. (2006). Bendravimo su vaikais, turinčiais ịvairaus lygio negalia, būdai ir technologijos. Vilnius: Progresus.

Melienė, R., Ruškus, J., Elejošienė, L. (2003). Didaktinių paradigmų realizavimas mokant specialiujų ugdymosi poreikių turinčius vaikus: stebėjimo bendrojo lavinimo mokyklos klasėje duomenys. Specialusis ugdymas, nr. 2 (9): 85-97.

Pagrindinio ugdymo bendrosios programos. Socialinis ugdymas. (2009). Lietuvos Respublikos švietimo ministerija. Prieiga internete: http://portalas.emokykla.lt/bup/Puslapiai/pagrindinis_ugdymas_socialinis_ugdymas_ bendrosios_nuostatos.aspx [žr. 20140105$].$

Pagrindinio ugdymo bendruju programu pritaikymo rekomendacijos. Specialiuju poreikiu mokiniu kalbiniam, matematiniam, socialiniam ir gamtamoksliniam ugdymui. (2009). Vilnius: LR Švietimo ir mokslo ministerija, Ugdymo plètotès centras.

Pritaikytų ir individualizuotų programų formos. (2011). Prieiga internete: http://www.lrspa.lt/index.php/lt/specialistams-mokytojams/36-siauliu-miesto-spec-pedagogu-etodines-tarybos-parengtos-programu-formos [žr. $20131220]$.

Pumputis, J. (1998). Specialiosios mokyklos VII-IX klasių žinios apie Lietuvos paviršių ir naudingąsias iškasenas. Specialusis ugdymas, nr. 1: 83-87.

Pumputis, J. (2002). Specialiujų poreikių mokinių istorijos vaizdinių ypatumai. Pedagogika, nr. 56: $158-162$.

Silva, J. C., Morgado, J. (2004). Support teachers' beliefs about the academic achievement of students with special educational needs. British journal of special education, vol. 31, no. 4: 32-38.

Stankutė, A. (2011). Nežymiai sutrikusio intelekto vaikų ugdymosi ypatumai. Prieiga internete: http://kristianaweebly.weebly.com/uploads/1/8/5/2/18524958/nezymiai_sutrikusio_intelekto_mokiniai.pdf [žr. 2013 12 20].

Subotkevičienè, R., Stanaitis, S. (2011). Geografijos mokytojų žinių, gebejjimų ir vertybių ypatumai. Pedagogika, nr. 102: 104-115.

Survutaite, D. (2012). Mokiniu, turinčiu specialiuju poreikiu, ikiprofesinio ugdymo raida Lietuvoje. Vilnius: Edukologija.

Šiaučiukènienė, L., Stankevičienė, N., Čiužas, R. (2011). Didaktikos teorija ir praktika. Kaunas: Technologija. Šiaučiukėnienè, L., Visockienė, O., Talijūnienė, P. (2006). Šiuolaikinès didaktikos pagrindai. Kaunas.

Vilkelienè, A. (2003). Vaiku, turinčiu specialiuju poreikių psichologinė raida. Šiaulių universiteto leidykla.

\section{GEOGRAPHY LESSONS FOR STUDENTS WITH MILD INTELLECTUAL DISABILITIES: SPECIAL EDUCATION}

\section{Regina Subotkevičienė}

\section{Summary}

The laws regulating the educational system of the Republic of Lithuania guard the right of every person to receive eligible education meeting the needs and abilities of such persons. One of the fundamental features of educational system is to create conditions for children with developmental disorders for learning according to individually planned programs adjusted to their abilities and to seek optimal learning achievements by applying special teaching aids and methods. It is emphasised that the compulsory education should be accessible to all children irrespective of their abilities and needs. 
Organisation of teaching / learning of students with special needs is a broad theme. There are many studies devoted to various phenomena of integrated teaching process: competence of teachers, adaptation of teaching programs, teaching procedures, attitude of teachers towards the changes of professional activity, organisation of the teaching/learning process for students with special needs, etc. Yet analysis of literary sources revealed that specific educational features of teaching geography to children with mild intellectual disorders remains a relevant issue in the Lithuanian comprehensive schools. The few available sources dealing with this issue are out-of-date and the given recommendations are designed for students at special schools. In the present article, specific education of students with mild intellectual disabilities and specific teaching / learning methods which could be successfully applied in teaching geography to the mentioned students are discussed based on analysis of literary sources and individual experience.

According to the data of World Health Organisation (WHO), about $11 \%$ of children are born with developmental impairments and disorders including $3 \%$ of children with intellectual disabilities. Commonly, such children are characterised by impaired logical thinking: analysis, comparison, generalisation, and formulation of conclusions. Their language is poor and has few generalising words. Due to inert thinking, the students are unable to use the acquired knowledge in new unusual situations. Their perception is visual rather than verbal. Bearing this in mind, the academic knowledge in teaching students with mild intellectual disability should be closely linked with practical activity and life experience and illustrated with concrete examples. Students with mild intellectual disability are characterised by deficit of wilful activity. They are able to act only with the help of adults. Yet such children are capable of participation in targeted activity when it meets their abilities. They are diligent, disciplined, dutiful, get upset over failures and are happy when succeed.

The specific cognitive features of students with mild intellectual disability predetermine considerable differences of general and individualised content. Yet the efficiency of educational programs is guaranteed only by adjustment of general and individualised content which can be achieved by integration of programs. Integrated education, targeted and consistent activity, achievable goals, good knowledge of the links between the social environment and life experience of children with mild intellectual disabilities, feasible tasks meeting their needs and abilities, and relevant teaching/learning methods and procedures are the key factors for overcoming difficulties and for development through learning different school subject.

The integrated education of students with special needs during lessons of different subjects has become a common phenomenon. However, as was already men- 
tioned, analysis of literary sources showed that specific education of students with different impairments, including the ones with mild intellectual disorders, during geography lessons remains a relevant yet little analysed problem in the Lithuanian comprehensive schools. The available material is either out-of-date or designed only for special schools.

The general goals of education of students with mild intellectual disorders are the following: to develop individual, social and cultural competences, to teach the elements of public spirit and functional skills in their environment, to teach elementary literacy, and to prepare students for professional and continuing education adjusted to their abilities. Geography is a system of sciences encompassing branches of natural and social sciences which study natural and productive territorial complexes and their components. It is one of the most integrated teaching school subjects displaying the integrity of nature and society in the mosaic world, spatial links between civilisations and cultures, interdependence between nature and society, and issues of their development and survival. In students with mild intellectual disability, geography helps to develop geographical world outlook and encourages interest in diversity of nature and society of own and other countries, and forms positive attitude towards their environment and safe behaviour in the natural and social environments. In order to achieve the mentioned goals, teachers of geography are expected to work out teaching strategies which would contribute to teaching students with special needs to learn, to be self-sufficient, to plan their time, and to practice skills of reading, listening, practical work and self assessment. The efficiency of the teaching strategies usually depends on the relevantly selected methods and procedures of teaching geography.

For integration of students with mild intellectual disorders during geography lessons it is important to take into account many factors: individual abilities of students, general programs, practical recommendations, teacher's competences, level of integrate class, microclimate in the class, subject content, complexity of the learning theme, quality of teaching aids and equipment, etc. The choice of relevant teaching / learning methods is not an easy task. Based on literary sources and individual experience, it is expedient to survey only some instruction methods applied in the integrated geography lessons which are rather effective in working with students with mild intellectual disability. Emphasis is placed on learning methods since they help to develop in students with intellectual impairments important abilities such as self-sufficiency of students, their activity, creativeness, and decision making. It should be pointed out that there cannot be any universal recommendations or good, perfect or bad methods. Students are different. Various learning methods can be ineffective even in students with the same impairment. 
Construction and planning of integrated geography lessons for students with mild intellectual disorders various classical methods of the use of information sources and operational and creative learning methods can be applied:

- Comparison of geographical objects is the method which can be used for distinguishing essential features through showing similar or different features.

- Narration following a plan. The plan is composed of a few (3-4) structural parts.

- Application of riddles and other genres of folklore (jokes, proverbs, etc.). The themes of riddles may be rather variable: things of inanimate nature, phenomena, people, etc.

- Consolidation of new geographical terms and notions. Various tasks can be applied, e.g. finding epithets, antonyms, and synonyms based on visual material.

- Completing sentences. Card with omitted words (related with teaching material) should be prepared.

- Completing tables. It is a method of consolidation of learned material. This method interest and mobilise students. It is recommended that tables are completed in exercise books adjusting this method with other visual methods: e.g. to complete weather table of chosen month.

- Completion of simple geographical crosswords. The first crosswords must be simple and small. The words to be inserted should be related with the subjects discussed at lessons.

- Completion of schemes. They should be simple, easily understandable and easily completed.

- Recognition and naming of natural objects and man-made objects (using natural objects and visual aids). This method is very important because of close links between words, images and practical activity.

Integrated geography lessons for students with mild intellectual disability also may be based on different creative methods, e.g. "Travelling around Europe", "Lithuanian regions and visiting sites", "How I get acquainted with Vilnius", etc. when students work with maps and describe different objects. This method requires active use of different sources and information technologies, quickens students' interest in geography, evokes positive emotions, and develops self-sufficiency.

Creation of the models of geographical objects is one more creative method helping to generate correct constructs. This method contributes to memorising the key features of objects. 
Analysis of literary data and individual experience shows that generation of images by students with mild intellectual disability is a rather complicated process. The traditional methods of creating geographical images based on verbal visual perception often produce no positive results. Teachers have to seek for novelties which would help students to create adequate mental images of geographical objects. The modern learning methods often are very helpful. One of such methods is "drawing in the air". Through heuristic conversation the teacher finds out what students know about a chosen object, compares it with the object present in the nearest environment, explains new material, demonstrates pictures, and compares them.

Various didactic games, e.g. "who will be the first to find the 5 longest rivers", game "yes or no", etc., also are very helpful during the integrated geography lessons. They are of corrective educational importance as they help to strengthen self-sufficiency of students.

Cooperative learning techniques, e.g. "work in groups", "mutual learning", "say and listen", etc. also can be applied in teaching students with mild intellectual disability. Learning by these methods helps students to feel real members of the class.

While constructing integrated geography lessons, it is possible to draw a rather long list of relevant teaching/learning methods. Yet it should be born in mind that all of them both have merits and drawbacks. Therefore, a decisive role is played not only by the severity of students' impairment but also by teacher's personality and ability to choose adequate teaching / learning methods which would enable the learning of students of any impairment. There cannot be no commonplace recommendations. Therefore, it can be stated that organisation of integrated geography lessons for students with mild intellectual disability is a real challenge to teacher's competence and skills. 
